\title{
THE EFFECT OF STEM NEMATODE INFESTATION ON PRODUCTIVITY AND PERSISTENCE OF LUCERNE CULTIVARS
}

\author{
M. W. DUNBIER, T. P. PALMER, T. J. ELLIS \\ AND P. A. BURNETT \\ Crop Research Division, DSIR, \\ Christchurch
}

Summary

A field trial was conducted to assess plant mortality and production losses of resistant and susceptible cultivars of lucerne (Medicago sativa) due to stem nematode (Ditylenchus dipsaci) in the presence of bacterial wilt (Corynebacterium insidiosum). Only cultivars resistant to stem nematode and bacterial wilt gave high yields and maintained adequate plant numbers in infected plots. Cultivars susceptible to either or both diseases had reduced yields and suffered high plant mortality. Cv. 'Gladiator' which had been described as resistant or tolerant to stem nematode was susceptible in this trial.

\section{INTRODUCTION}

Stem nematode is an important pest of lucerne in New Zealand but no field evidence is available on the production losses or plant mortality it causes. The trial reported in this paper aimed to provide information on these.

\section{MATERIALS AND METHODS}

The trial design was a split plot with infection with stem nematode versus non-infected controls as main plots and cultivars as sub-plots. The whole area was infected with bacterial wilt. The reported disease and pest resistances of the cultivars used are shown in Table 1. Details of establishment, field layout, inoculation technique and statistical procedures have been described previously (Dunbier et al 1978) in a progress report on the experiment. Yield cuts were taken regularly ( 3 in the $1975 / 6$ season, 5 in each of $1976 / 7$ and $1977 / 8$ ) but the final plant count was not taken until February 1979 . The trial was spray irrigated whenever necessary to maintain vigorous growth. Plant survival percentages were analysed using the square root transformation and those percentages presented are back-transformed means.

\section{RESULTS AND DISCUSSION}

Plant survival figures are presented in Table 1. The original plant density was 33 plants $/ \mathrm{m}^{2}$ which is about equivalent to a mature stand density, and sufficient to give maximum production in Canterbury (Palmer and Wynn-Williams 1976). This density was chosen so that results would simulate the effect of stem nematode infection in an established stand. There were few deaths in the first season after inoculation although plant numbers of cvs 'Wairau' and 'Apalachee' were significantly reduced in infected plots after 12 months. Considerable plant mortality occurred over

Proc. 32nd N.Z. Weed and Pest Control Conf. 
the next two seasons however; so by March 1978 (23 months after infection) only cvs 'Washoe,' 'Lahontan' and 'Resistador II' maintained a satisfactory stand. Comparison of plant numbers from infected and control treatments indicate deaths from stem nematode, but in the presence of bacterial wilt. There are three major points from Table 1. Firstly, numbers of plants of the nematode susceptible crs Wairau and 'Saranac' were significantly reduced by stem nematode. Gladiator, which has been described as resistant (Anon., Report Committee on Varietal Descriptions, Alfalfa Improvement Conference Report 1974), or moderately tolerant (Marble 1978) to stem nematode, was also reduced in population and on these results was susceptible to stem nematode. Glasshouse tests reported by Burnett et al (1979) have confirmed that Gladiator is susceptible to a local stem nematode population. Differences in virulence of stem nematode populations in North and South America have been reported (Grundbacher and Stanford 1962; Smith 1951). More studies would be required to determine if New Zealand stem nematode populations differed in virulences from those in North America. The relatively poor survival of Gladiator in the control plots cannot be adequately explained, as it is resistant to bacterial wilt (Marble 1978; Dunbier, unpubl. data). Alfa II and Apalachee, although resistant to stem nematode, are very susceptible to bacterial wilt (Dunbier unpublished) and this is probably sufficient explanation for their poor survival. Finally, Washoe, Lahontan and Resistador II showed good resistance to both diseases and they survived well in both treatments.

The dry matter yields for each season are presented in Table 2. Dry matter yields of susceptible cultivars were reduced significantly in the third cut of the $1975 / 6$ season, immediately after infection with stem nematode and before any plant mortality was apparent. In the 1976/7 season the susceptible cultivars Wairau, Saranac and Gladiator were significantly reduced in yield in infected plots, mainly in the first three cuts. This yield loss was recorded before there was any reduction in plant population (Table 1, "12 months" column). The major yield reduction in the nematode-infected plots came in the $1977 / 8$ season, when there was a major loss of plants. A valid estimate of the effect of stem nematode on yield of bacterial wilt resistant cultivars is found by comparing infected and control plots of Saranac (resistant only to bacterial wilt) and Washoe, Lahontan and Resistador II (resistant to stem nematode and bacterial wilt). The yield of Saranac was 35\% less in infected plots whereas Washoe, Lahontan and Resistador II yielded as much in infected as in control plots.

The production losses from individual cuts of Saranac and Washoe over the 1977/8 season are shown in Fig. 1. Infected Saranac plots yielded significantly less than controls in all cuts, although the biggest loss was in the first cut. Infected Washoe yielded less in the first cut only. It has been considered that stem nematode causes large yield reductions only in the first cut, (Wood 1972) but clearly where there is significant plant mortality yield of later cuts is also reduced.

The overall production figures show that in the control plots there are relatively small yield differences between cultivars. In the infected plots however there are large differences in yield. Cultivars that intially had the highest production e.g., Alfa II and Apalachee had by the end of the trial been surpassed in total yield by the bacterial wilt and stem nematode resistant cultivars Lahontan, Washoe and Resistador II whose superior persistence is reflected in their superior performance in infected plots over the $1977 / 8$ season.

More important than total yield over the short term of this trial however is plant survival. In contrast to the other cultivars Lahontan, Washoe and Resistador II maintained sufficient plant numbers for future production. 


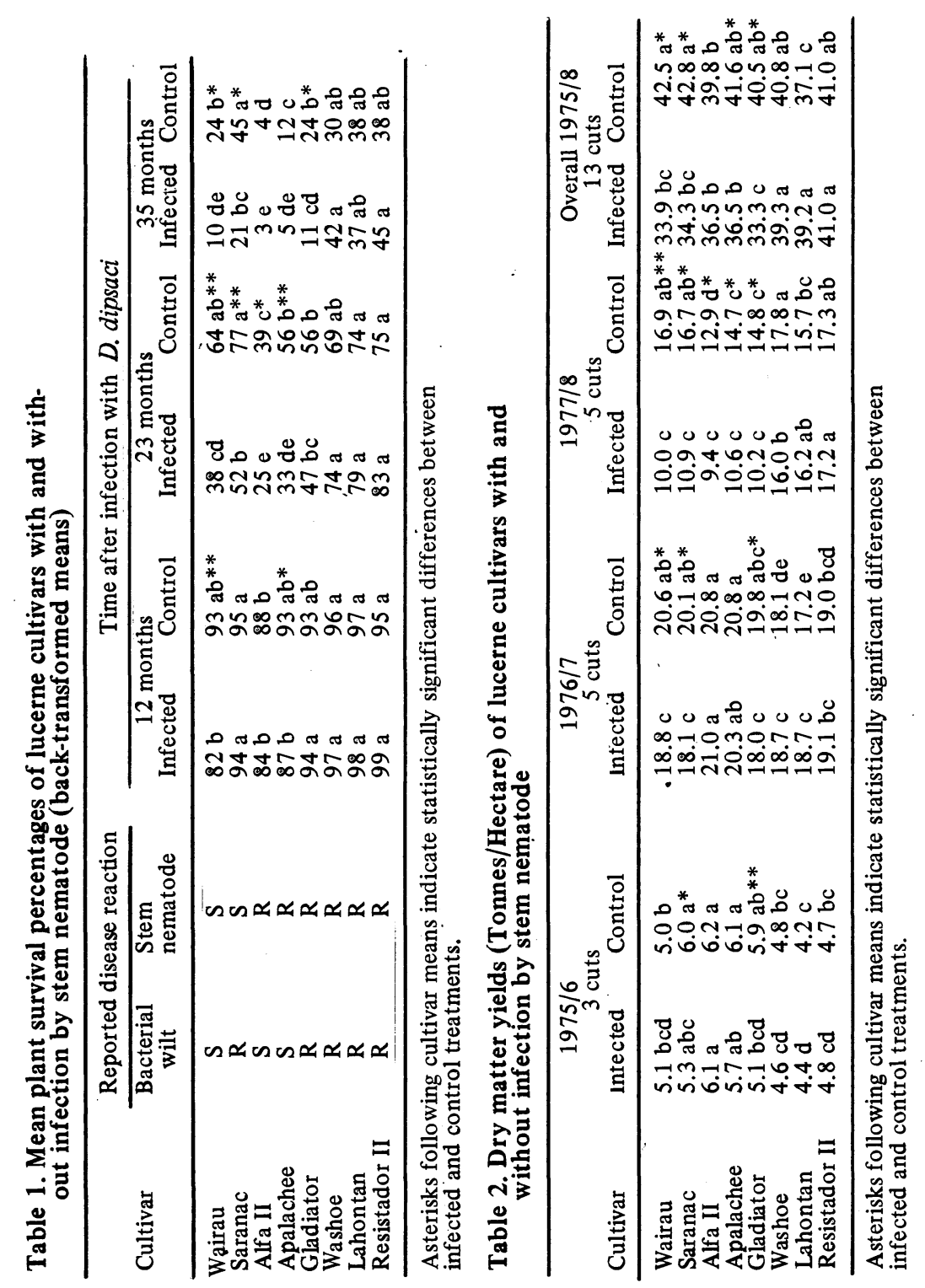

197 


\section{Nematodes}

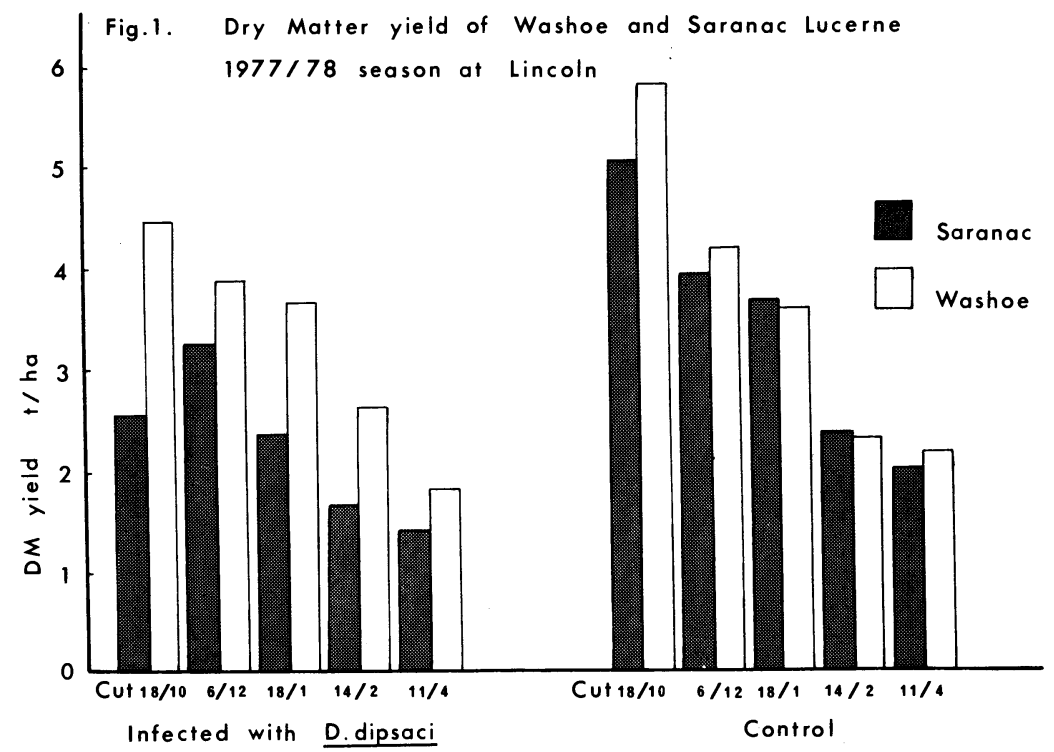

The conclusion to be drawn from this trial is that in areas where there is stem nematode infection along with bacterial wilt cultivars resistant to both of these will not only give greater total yield but provide at least one season's extra production.

\section{REFERENCES}

Dunbier, M. W., Palmer, T. P., Ellis T. J., and Bennett, P. P., 1978. Field evaluation of lucerne cultivars for stem nematode and blue-green aphid resistance in New Zealand. Proc. 2nd Aust. Conf. Grassland Invert. Ecology. In Press.

Grundbacher, F. J. and Stanford, E. H., 1962. Genetic factors conditioning resistance in alfalfa to the stem nematode. Crop Science 2: 211-217.

Marble, V. L., 1978. Alfalfa variety characteristics and adaptation in California. 8th California Alfalfa Symposium Proceedings, Co-operative Extension, University of California 11-21.

Palmer, T. P. and Wynn-Williams R. B., 1976. Relationships between density and yield in lucerne. N.Z. J. Exp. Agric. 4: 71-77.

Smith, Oliver F., 1951. Biologic races of Ditylenchus dipsaci on alfalfa. Phytopathology 41: 189-190.

Wood F. H., 1972. Biology, incidence and general control of the lucerne stem nematode. Proc. 25th N.Z. Weed and Pest Control Conf.: 116-121. 